\title{
Virtual Seminar: an innovative educational experience
}

\section{Seminário Virtual: uma experiência educacional inovadora}

\section{Lina Maria Martinez-Sanchez ${ }^{1}$ (]) Yuban Sebastian Cuartas-Agudelo ${ }^{2}$ (1) Alejandro Hernandez-Martinez ${ }^{3}$ (1) Laura Herrera-Almanza ${ }^{4}$ (1) Miguel Saavedra-Valencia 5}

\author{
1-4Universidad Pontificia Bolivariana. (Medellín) Colombia. linam.martinez@upb.edu.co \\ Yuban.cuartas@upb.edu.co, alejandro.hernandez@upb.edu.co, laura.herreraa@upb.edu.co \\ ${ }^{5}$ Corresponding author. Universidad Pontificia Bolivariana. (Medellín) Colombia. miguel.saavedra@upb.edu.co
}

\begin{abstract}
INTRODUCTION: It is of special importance that teachers can easily transmit knowledge using didactical tools such as Cmaptools, Slideshare, YouTube, among others. Because of that, teaching methods nowadays are going through a revolution that implies technological development and the arrival of new generations. OBJECTIVE: describe the experience of developing a virtual education strategy in our institution to improve the teaching and learning process and facilitate interaction with students. METHODOLOGY: the students must do a bibliography search in databases (PubMed, Science Direct, and Embase), choosing one recent (published within the previous 3 months) original article in English. The article must involve the use of molecular techniques that include some electrophoresis, then get a tutoring session with the main teacher of the course. After that, the student must design a PowerPoint slideshow of a maximum of 15 slides. Finally, they have to record a 10-minute-long video of the presentation. The video must be uploaded to the YouTube website. RESULTS: a greater comprehension of the seminar presentation dynamic was observed compared to the previous methodology, which did not include the virtual component. CONCLUSIONS: The implementation of new innovative methodologies in education allows students to develop a broader learning process, besides improving their scientific understanding; they improve their knowledge on technological tools implemented in education
\end{abstract}

RESUMO | INTRODUÇÃO: É de especial importância que os professores possam transmitir facilmente o conhecimento utilizando ferramentas didáticas como o Cmaptools, SlideShare, Youtube, entre outros. Por causa disso, os métodos de ensino nos dias de hoje estão passando por uma revolução que implica desenvolvimentos tecnológicos e a chegada de novas gerações. METODOLOGIA: os estudantes devem fazer uma pesquisa bibliográfica em bases de dados (PubMed, Science Direct, e Embase) escolhendo um artigo original recente (publicado nos 3 meses anteriores) em inglês. $O$ artigo deve envolver o uso de técnicas moleculares que incluam algum tipo de electroforese para depois receberem uma sessão de tutoria com o professor principal do curso. Em seguida, o aluno deve conceber um slideshow em PowerPoint com no máximo 15 slides. Finalmente, devem gravar um vídeo de 10 minutos de duração da apresentação. O vídeo deve ser carregado no website do YouTube. RESULTADOS: uma maior compreensão da dinâmica de apresentação de seminário foi observada em comparação com o método anterior, que não incluiu o componente virtual. CONCLUSÕES: a implementação de métodos inovadores na educação permite aos alunos desenvolver um processo de aprendizagem mais amplo, além de melhorar seu entendimento científico; eles melhoram o seu conhecimento em ferramentas tecnológicas implementadas na educação.

PALAVRAS-CHAVE: Educação Médica. Ensino. Aprendizagem.

KEYWORDS: Education. Medical. Teaching. Learning. 


\section{Introduction}

Most higher education institutions in Colombia and other countries have a medical school curriculum divided into 2 cycles: basic sciences and clinical sciences. The basic portion of the curriculum includes courses such as biochemistry, anatomy, histology, microbiology, pathology, physiology, cellular and molecular biology, among others, while the clinical cycle includes courses on internal medicine, psychiatry, general surgery, among others. It is important to improve education so that new technologies and methodologies are not ignored due to lack of knowledge or denial. - $-6^{-6}$

Health professionals, as well as any other professional, must be able to remain current in their area of expertise. When reading scientific articles, information must be evaluated by applying and transposing previously acquired concepts with those expressed in such texts, assuming a critical position in terms of the methodologies and results.

Additionally, it is of vital importance to be able to pass on what has been read simply, making use of didactical tools, such as conceptual maps, through the acquired knowledge and the implementation of a foreign language such as English. $\underline{\underline{T}}$ At the same time, Information and Communication Technologies (ICT) allow achieving this transmission of ideas; building and being part of the global society we live in nowadays., Digital resources such as PowerPoint allow a presentation adjusted to the topics of the presenter, and the software Cmaptools permits the standardized design of conceptual maps for easy interpretation by fellow users. In addition, by using platforms like Slideshare and YouTube, the sharing of information is greater, and, thus, the sharing of knowledge..$^{10-16}$

The use of digital platforms and scientific seminars allows interaction and feedback between students, which improves the autonomy and commitment to the duties of the subject, familiarizing them with scientific languageand increasing their confidence and knowledge in the medical field., $.16-19$
Active learning is a tool that seeks to increase interaction between the student and the teacher, encouraging participation inside and outside the classroom. There are currently many active learning strategies, including problem-based learning, inverted classroom, and Feynman's technique, among others. These activities facilitate discussion of the topic and motivate the student to ask questions, investigate and search for answers on their own. ${ }^{20,21}$ Virtual seminars represent an opportunity for students to debate their ideas and opinions, question their previous knowledge, test hypotheses, and develop new concepts, becoming better thinkers and creating a basis for future learning. 20,21

However, the teaching of medicine in the classroom has not changed at the same pace as medical practice and scientific information. With the traditional lecture format still maintained, it can be stated that the change in teaching methods is slow even though most teachers are familiar with active learning strategies. 22 According to Bucklin, $80 \%$ of teachers use active learning strategies in less than half of their activities. 22

It is important to increase the dissemination of learning strategies and contribute to educational innovation. Because of that, a private university from Medellín, in the Molecular Biology course during the third semester of medicine, developed a methodology that could improve student learning, so this article is intended to describe the experience of developing a virtual education strategy in our institution to enhance the teaching and learning process and facilitate interaction with students.

\section{Academic seminar}

The academic seminar consists of a presentation of a specific topic, article discussion, and research presentation, among other activities. All these activities are provided to evaluate and give feedback to students. $\frac{23}{}$ The seminar requires certain aptitudes from the student such as oral expression and body language, appropriate speech, and controlling stage fright, inter alia. 14,24 The correct implementation of this strategy allows an improvement on topic presentation abilities. 


\section{Experience development}

The molecular biology course includes both theory and practice, we evaluate lecture bibliography, teacher-provided bibliography, and integration to other courses and areas of the basic teaching cycle, always procuring a practical approach, focusing on the needs of a Medical Professional rather than those of a Molecular Biologist, establishing an adequate relation between clinical practice and theory.

With aims to guarantee the development of capacities and proficiencies required for a critical analysis of scientific articles and the pragmatic use of ICT, the Molecular Biology course of the Faculty of Medicine designed an activity, which consists of an oral presentation of a scientific article. The instructions for the activity are given to each of the students; tutors and teachers give tutoring sessions before the exposition. Furthermore, to make the students' analysis easier, we included the design of a conceptual map that must be incorporated into the article presentation.

The seminar started as a strategy under the model of face-to-face learning, using applications such as Slideshare and Cmaptools; beginning in 2018, a new strategy for this activity was developed, in which each student would present the seminar in the following way:

First, before the beginning of the academic activities, each student receives the instructions and deadlines for the virtual seminar on their university email. Then, they must do a bibliography search in databases (PubMed, Science Direct, and Embase), choosing one recent (published within the previous three months) original article in English. The article must involve the use of molecular techniques that include some electrophoresis concerning the course topics. Later, the article is reviewed and approved by teachers and tutors.

Second, students get a tutoring session with the main teacher of the course, where they are given further instructions on the structure of the presentation and where both get to clarify concepts. Nonetheless, if the student might need to clarify other concepts during the preparation of the seminar, tutors are available for that matter.

Third, the student must design a PowerPoint slideshow of a maximum of 15 slides. The slideshow must include fragments in both English (introduction, objective, conclusions, and concept map) and Spanish (methodology), or, if the student decides to, the slideshow can be fully presented in English, including the development of a concept map in Cmaptools, disclosing the general idea of the article's topic. Subsequently, the presentation must be uploaded to the website Slideshare.

Fourth, students must record a 10-minute-long video of the presentation with optimal quality, both in sound and image. Thereupon, the video must be uploaded to the YouTube website, and the student is required to send the video link to the main teacher to be evaluated.

The activity is carried out every semester with approximately 60 students, and each student is responsible for making the video with the presentation of the selected article. The other classmates must watch the video and comment on the topic discussed.

Feedback of the work is done using a rubric elaborated by the teachers of the area and evaluates aspects like quality of the video and audio, design of the slides and use of audiovisual tools, management of the topic, use of English, among others. Finally, the results are sent to the students to know their grades and recommendations.

\section{Purpose of the experience and critical reflection}

The virtual seminars on research articles allow the student to become familiar with the use of databases and academic reading and encourage self-taught research, but without forgetting the accompaniment and guidance of the teacher. With this learning tool, the student is motivated to ask questions, develop critical thinking, and improve their ability to solve problems.

Through the implementation of this strategy, students improved their ability to read scientific articles, 
interpret graphs, and analyze the results of molecular biology laboratory tests, and these competencies were useful for understanding the course topics.

The limitations of this academic experience arise in the technical aspects of video creation, such as video editing and its transitional and audiovisual effects, because most students do not have skills in audiovisual programs, and the training in these skills are not included in the current medical program. Furthermore, even though the instructions were sent months ago, and the delivery date of the seminar was emphasized, the students presented multiple difficulties in this regard, evidenced by the delay in their deliveries and the multiple requests for additional time to complete the objective. Another limitation evidenced is that some students reported having an inadequate or inefficient internet connection, which continues to be a limitation in the Colombian territory and other Latin American countries because access to the network is not guaranteed for everyone.

The results of this academic experience are replicable in different academic fields of basic biological sciences, the clinical field, and even in other areas of knowledge, due to the simple design of the strategy used and the facility of the students to do the seminar through ICT. In addition, the methodology favors the replication for multiple reasons, principally because the academic contents are constantly updated, and the use of technological aids and tools are increasingly in different subjects and university classrooms, which is why it is also presented as an opportunity for others educational institutions take in, replicate, and improve this strategy with their students. Furthermore, given the emergence of virtuality in the world, it is important to promote the development of these capacities in the students because they facilitate and provide them with new tools in their learning processes.

The implementation of the virtual seminar brings with it the possibility of increasing technical knowledge in medicine and integrating it with other knowledge, including communication and digital skills, which are increasingly necessary for the professional field. At the same time, this methodology allows diversifying the learning experience where the student is the protagonist with a greater understanding and appropriation of the topic to be presented, facilitating the learning process through the sharing of knowledge and interaction between peers in new spaces for it. This leads to professional training with technical knowledge of their specific area of knowledge complemented with the ability to develop materials and resources that allow them to communicate the message easily and efficiently. This capacity is widely necessary for the medical future. In their daily practice, it is vital to provide education to patients and their families, which facilitates the process of disease prevention and adherence and proper use of medication and indications provided.

Finally, the experience was developed to facilitate the learning process of the course's topics, making use of technological tools that, in many cases, are not exploited, emphasizing laboratory techniques for disease diagnosis, which represent the boom of modern medicine.

\section{Evidence of the experience}

During the implementation of the strategy, a lot of outstanding presentations were obtained, showing the students' abilities to develop academic activities using new information technologies. Some highlighted YouTube presentations from students are found below:

- https://www.youtube.com/watch?v=y3FgivjidPA

- https://www.youtube.com/watch?v=K27.jpmqt7q0

\section{Conclusion}

This strategy made it possible for students to learn new ways of knowledge sharing. It is a way of facilitating learning while being evaluated in the Molecular Biology course. Implementing new innovative methodologies in higher education may allow students to develop a complete learning process. Besides allowing for an easier process, these kinds of methodologies use technological tools that intend to improve the continuity of the academic sphere. 


\section{Authors' contributions}

Martinez-Sanchez LM, Martinez-Hernandez A, Herrera-Almanza $L$ participated in conceptualization, formal analysis, research, methodology, project management, resources, supervision, validation, visualization, writing - original draft, proofreading, and editing. Cuartas-Agudelo YS participant in conceptualization, formal analysis, research, methodology, project management, resources, writing - original draft, review, and edition. Saavedra-Valencia ME participated in the formal analysis, research, methodology, design, supervision, writing - proofreading, and editing.

\section{Competing interests}

No financial, legal, or political competing interests with third parties (government, commercial, private foundation, etc.) were disclosed for any aspect of the submitted work (including but not limited to grants, data monitoring board, study design, manuscript preparation, statistical analysis, etc.).

\section{References}

1. Castrillón JJC. La reforma curricular del Programa de medicina de la universidad de Manizales. Arch Med (Manizales) [Internet]. 2012;12(2):137-9. Available from: https://www.redalyc.org/ pdf/2738/273825390008.pdf

2. Múnera EMV, Rave ÁMA, Muñoz CA. La renovación curricular en el programa de Medicina de la Universidad de Antioquia. Iatreia [Internet]. 2007;20(4):422-44. Available from: https://revistas. udea.edu.co/index.php/iatreia/article/view/4425

3. Forero DA, Majeed MH, Ruiz-Díaz P. Current trends and future perspectives for medical education in Colombia. Med Teach. 2020;42(1):17-23. https://doi.org/10.1080/0142159x.2019.1659944

4. Franco RLO, Machado JLM, Grinbaum RS, Porfírio GJM. Barriers to outpatient education for medical students: a narrative review. Int J Med Educ. 2019;10:180-90. https://dx.doi. org/10.5116\%2Fijme.5d76.32c5

5. Mureșan S, Meda-Georgescu A, Azamfirei L, Oana-Marginean C, Cm-Taylor D. Medical education in Romania: Tradition and innovation. Med Teach. 2019;41(6):619-24. https://doi. org/10.1080/0142159X.2018.1552932

6. Rohlfsen CJ, Sayles H, Moore GF, Mikuls TR, O'Dell JR, McBrien $\mathrm{S}$, et al. Innovation in early medical education, no bells or whistles required. BMC Med Educ. 2020;20(1):39. https://doi.org/10.1186/ s12909-020-1947-6
7. Kurata S, Fujiki T, Murota M. Developing an online video presentation evaluation system to promote mutual evaluation and survey of operability [Internet]. Proceedings of the 24th International Conference on Computers in Education; 2016; India. Available from: http://www.et.iitb.ac.in/icce2016/files/ proceedings/ICCE\%202016\%20Main\%20Conference $\% 20$ Proceedings.pdf

8. Ferreira PB, Cohrs CR, De Domenico EB. Software CMAP TOOLS TM to build concept maps: an evaluation by nursing students. Rev Esc Enferm USP. 2012;46(4):967-72. https://doi.org/10.1590/ s0080-62342012000400026

9. Tackett S, Wright SM, Quirk M. Adaptive medical education research. Med Teach. 2018;40(8):783-5. https://doi. org/10.1080/0142159x.2018.1490705

10. Rodríguez-Ríos A, Espinoza-Téllez G, Martínez-Ezquerro JD, Rendón-Macías ME. Information and Communication Technology, Mobile Devices, and Medical Education. J Med Syst. 2020;44(4):90. https://doi.org/10.1007/s10916-020-01559-w

11. Lifshitz-Guinzberg A, Abreu-Hernández LF, SepúlvedaVildósola AC, Urrutia-Aguilar ME, Córdova-Villalobos JÁ, LópezBárcena J, et al. Pros and cons of innovations in medical education. Gac Med Mex. 2021;157(3):325-34. https://doi. org/10.24875/gmm.m21000568

12. Pontes-Pedrajas A. Representación y comunicación del conocimiento con mapas conceptuales en la formación del profesorado de ciencia y tecnología. Revista Eureka sobre Enseñanza y Divulgación de las Ciencias [Internet]. 2012;9(1):106-23. Available from: https://helvia.uco.es/bitstream/ handle/10396/8134/7 Pontes 2012.pdf?sequence=1

13. Fatima A, Zaman S, Asim HM. Educational outcome in scenario and powerpoint presentation based learning strategies among undergraduate physical therapy students. Rawal Med J [Internet]. 2018;43(1):146-50. Available from: https://www.rmj.org.pk/ fulltext/27-1501583247.pdf

14. Ginkel S, Gulikers J, Biemans H, Mulder M. Towards a set of design principles for developing oral presentation competence: A synthesis of research in higher education. Educ. Res. Rev. 2015;14:62-80. https://doi.org/10.1016/j.edurev.2015.02.002

15. Crow J, Murray JA. Online Distance Learning in Biomedical Sciences: Community, Belonging and Presence. Adv Exp Med Biol. 2020;1235:165-78. https://doi.org/10.1007/978-3-030-37639-0 10

16. Kecskes Z, Mitchell I. Introducing a new series on innovations in medical education. Med J Aust. 2017;206(1):13. https://doi. org/10.5694/mja16.01212 
17. Nadama HH, Tennyson M, Khajuria A. Evaluating the usefulness and utility of a webinar as a platform to educate students on a UK clinical academic programme. J R Coll Physicians Edinb [Internet]. 2019;49(4):317-322. Available from: https:// www.mja.com.au/journal/2017/206/1/introducing-new-seriesinnovations-medical-education

18. Kay D, Pasarica M. Using technology to increase student (and faculty satisfaction with) engagement in medical education. Adv Physiol Educ. 2019;43(3):408-13. https://doi.org/10.1152/ advan.00033.2019

19. Adams K. Modelling success: Enhancing international postgraduate research students' self-efficacy for research seminar presentations. High. Educ. Res. Dev. 2004;23(2):115-30. https:// doi.org/10.1080/0729436042000206618

20. Torralba KD, Doo L. Active Learning Strategies to Improve Progression from Knowledge to Action. Rheum Dis Clin North Am. 2020;46(1):1-19. https://doi.org/10.1016/j.rdc.2019.09.001
21. Quintanilha LF, Costa GN, Coutinho MR. Medical student perceptions about active methodologies in the study of physiology in medical schools in Salvador, Brazil. Adv Physiol Educ. 2018;42(4):693-6. https://doi.org/10.1152/advan.00105.2018

22. Bucklin BA, Asdigian NL, Hawkins JL, Klein U. Making it stick: use of active learning strategies in continuing medical education. BMC Med Educ. 2021;21(1):44. https://doi.org/10.1186/s12909020-02447-0

23. Almarzooq ZI, Lopes M, Kochar A. Virtual Learning During the COVID-19 Pandemic: A Disruptive Technology in Graduate Medical Education. J Am Coll Cardiol. 2020;75(20):2635-8. https://pubmed. ncbi.nlm.nih.gov/32304797/

24. De Gerz L, Valcke M, Roozen I. The impact of an innovative instructional intervention on the acquisition of oral presentation skills in higher education. Comput Educ. 2009;(53):112-20. https:// doi.org/10.1016/j.compedu.2009.01.005 